\title{
Potential of Pseudomonas stutzeri strains isolated from rhizospheric soil endowed with antifungal activities against phytopathogenic fungus Stemphylium botryosum
}

\author{
SLIMANE MOKRANI ${ }^{1,2}$, BILEL BEJAOUI $^{3}$, LAKHDER BELABID ${ }^{2}$, EL-HAFID NABTI ${ }^{1, \bullet}$ \\ ${ }^{1}$ Laboratoire de Maitrise des Energies Renouvelables, Faculté des Sciences de la Nature et de la Vie, Université de Bejaia, 06000 Bejaia, Algeria \\ ${ }^{2}$ Department of Agronomy, Faculty of Biology, University of Mascara, Laboratory of Research on Biological Systems and Geomantic, P.O. Box 305, \\ 29000 Mascara, Algeria. "email: nabtielhafid1977@yahoo.com \\ ${ }^{3}$ Higher Institute of Biotechnology, University of Manouba, Laboratory of Biotechnology and Bio-Geo Resources Valorization, Sidi Thabet Biotechpole, \\ 2020 Sidi Thabet, Ariana, Tunisia
}

Manuscript received: 20 September 2019. Revision accepted: 21 October 2019.

\begin{abstract}
Mokrani S, Bejaoui B, Belabid L, Nabti E. 2019. Potential of Pseudomonas stutzeri strains isolated from rhizospheric soil endowed with antifungal activities against phytopathogenic fungus Stemphylium botryosum. Asian J Agric 3: 47-54. In this study, two Pseudomonas strains P4 and P5 were isolated from rhizospheric soil and characterized for PGP (Plant Growth Promoting) traits production like HCN (hydrogen cyanide), siderophores and IAA (Indole Acetic Acid). A phylogenic tree based on 16S DNAr identification-related the two strains P4 and P5 to Pseudomonas stutzeri NR 116489 and NR 113652.1. One phytopathogenic fungus Stbt (Stemphylium botryosum) was isolated from Phaseolus vulgaris L. Macroscopic and microscopic identification attributed it to the genus Stemphylium. Antifungal activities of the two Pseudomonas strains P4 and P5 against fungus isolate St-bt had revealed very highly significant inhibition percentages of $38.46 \pm 3.85 \%$ and $56.56 \pm 2.22 \%$ for each strain, respectively.
\end{abstract}

Keywords: Antifungal activity, PGP traits, Pseudomonas stutzeri, Stemphylium botryosum

\section{INTRODUCTION}

Agriculture is the groundwork for food industries on a global scale. Sustainable agriculture strives to continue improving without compromising the environment (Gimenez et al. 2018). It is described as a system protecting manufacturing in the long conduct, except degrading of the natural properties, including the useful resources of the low-input applied sciences utilization (Altieri 1989; Saleh et al. 2017). On different sides, contemporary agriculture faces the extensive assignment of supplying a world population within continuous increase with food, at the same time as the natural sources augment to remain equal (González de Molina et al. 2017). Especially with abiotic stress prerequisites such as drought, heat, and salinity causing big losses in conformity with agricultural production worldwide. Also, the environment heterogenic conditions and world climatic changes are only a few of the challenges facing modern agriculture (Mittler and Blumwald 2010).

Furthermore, biotic stress is described as caused by plant living microorganisms that comprise fungi, bacteria, viruses, parasites, weeds, insects, and distinctive native and cultivated plants (Newton et al. 2011). Although fungal phytopathogens are considered causal agents on primary plant diseases, they can infect a range of plant components. This can include roots, stems, leaves, vegetation, and fruits; inducing characteristic visible symptoms as spots, blights, anthracnose, wilts, rots, etc. (Thilagam et al. 2018). In addition, microbial diseases caused about $16 \%$ of the loss of annual manufactured tonnage worldwide at the start of the 21 st century. $70-80 \%$ of these losses have been caused by fungi (Moore et al. 2011). To face all its constraints, chemical fungicides are extensively used for many plant disease treatments. Whereas these products can cause environmental pollution and disastrous effects on human health (Agrios 1988). The intensive uses of certain chemical compounds have influenced the improved resistance of the targeted organisms against certain chemicals (Goldman et al. 1994). However, biological control may remain a promising alternative in imitation of chemical elements to manage phytopathogenic fungi (Wallace et al. 2017; Tagele et al. 2018) and afford attractive dietary supplements among methods due to the limited environmental pollution (Compant et al. 2005; Nogórska et al. 2007).

The biological control entails the utilization of salutary organisms, their genes and/or gene products, such as metabolites that lessen the negative effect of plant pathogens and promote high-quality plant products (Vinale et al. 2008). Several microorganisms such as bacteria, fungi, viruses, algae, and protozoa have been recommended as individual or combined effective biopesticides (Chauhan et al. 2018).

The microbe can control a variety of pests (Nobutaka 2008), particularly a wide range of bacterial genera that can be used as biocontrol agents PGPR (Plant Growth Promoting Rhizobacteria) such as Azospirillum, Alcaligenes, Arthrobacter, Acinetobacter, Bacillus, Burkholderia, Enterobacteria, Pseudomonas, Rhizobium and Serratia (Goswami et al. 2016). Among these bacteria, 
Pseudomonas spp. are aerobic, gram-negative bacteria, ubiquitous in agricultural soils, and adapted in broad range growing area in the rhizosphere (Weller 2007). Pseudomonas possesses many traits to make them suitable for biocontrol and growth-promoting agents (Wei et al. 1996; Morrissey et al. 2004a; Stockwell and Stack 2007; Mishra and Arora 2017). The current study aimed to characterize the antifungal activities of two Pseudomonas strains endowed with PGPR characteristics against some phytopathogenic fungus isolate St-bt.

\section{MATERIALS AND METHODS}

\section{Origin of Pseudomonas strains}

In a previous study (Mokrani et al. 2019) two Pseudomonas strains P4 and P5 were isolated in 2010 from rhizospheric soil of Phaseolus vulgaris $\mathrm{L}$ from Tighanif Mascara $\left(35^{\circ} 24^{\prime} \mathrm{N} 0^{\circ} 19^{\prime} \mathrm{E}\right)$. The strains were stored in TSB (Tryptic Soy Broth) broth supplemented with $25 \%$ glycerol by sub-culturing every 12-18 months.

\section{Phylogenic identification of Pseudomonas strains DNA extraction and PCR amplification}

Genomic DNA of the two strains, P4 and P5, were extracted using the technique of phenol/chloroform/ isoamyl alcohol according to (William et al. 2012). PCR amplifications were performed using the following primers: Amorce Formed 16S Forward (5'-AGA GTT TGA TCC TGG CTC AG-3') and Amorce reverse 16S Reverse (5'CTA CGG CTA CCT TGT TAC GA-3') for 16S rRNA gene. 35 cycles were realized with the following conditions: preheating at $94^{\circ} \mathrm{C}$ for $3 \mathrm{~min}$; denaturation at $94^{\circ} \mathrm{C}$ for $45 \mathrm{sec}$; hybridization at $55^{\circ} \mathrm{C}$ for $1 \mathrm{~min}$; elongation at $72^{\circ} \mathrm{C}$ for $2 \mathrm{~min}$; final elongation at $72^{\circ} \mathrm{C}$ for 7 min and final cooling at $4^{\circ} \mathrm{C}$ for $7 \mathrm{~min}$ (Mokrani et al. 2018a).

\section{S DNAr sequencing}

Partial 16S DNAr was compared with the nucleotide sequences from international databases using BLAST (Basic Local Alignment Search Tool Program). The alignments of the nucleotide sequences were conducted out by using the Clustal $\mathrm{W}$ algorithm. The phylogenetic tree was obtained by MEGA 7 software program and the neighbor-joining algorithm. Bootstrap values have been determined from 100 replicates.

\section{PGPR analysis}

\section{Production of $\mathrm{HCN}$}

Hydrogen cyanide $(\mathrm{HCN})$ production was carried out as described by Lorck (1948). Bacterial strains were streaked on nutrient agar supplemented with $0.44 \%$ L-glycine. The change of color from yellow to light brown or red-brown indicated a moderate or high production of $\mathrm{HCN}$, respectively (Trivedi et al. 2008).

\section{Siderophores synthesis}

Siderophores determination was carried out by qualitative detection on a Chrome Azurol-S (CAS) agar medium. Pseudomonas strains were streaked on Petri dish plates containing CAS medium and incubated at $30{ }^{\circ} \mathrm{C} / 48 \mathrm{~h}$. Formation of orange halos surrounding colonies indicated siderophore production (Yeole et al. 2001).

\section{IAA production}

Qualitative IAA production. Bacterial strains were examined to produce Indole Acetic Acid (IAA) by the technique described by Bric et al. (1991). Bacterial strains were inoculated in Petri dish plates containing Luria Bertani (LB) medium supplemented with $5 \mathrm{mM} \mathrm{L}$ tryptophan. Production of IAA and/or its analogs in the medium manifested by leading to a red-pink color. For other indoles, color produced was yellow or brown-yellow.

IAA chromatography. To confirm the IA chromatography of IAA extracts was done according to the technique reported by (Kuang-Ren et al. 2003, modified). Pseudomonas strains were cultured on TSB (Tryptic Soy Broth) and incubated at $30{ }^{\circ} \mathrm{C} / 24 \mathrm{~h}$. After incubation, centrifugation was carried out and the supernatants were recuperated and mixed with ethyl acetate (1:2). After vigorous stirring, the partial extracts of the solvent layer were allowed to rest for $10 \mathrm{~min}$. The procedure was repeated 3 to- 4 times. Then, IAA chromatography was executed using dissolvent system propanol: water $(8: 2)$. Chromatogram of two IAA extracted samples and control (10 mg/100 mL about IAA) were developed with Salkowski's reagent.

\section{Fungus isolation and identification}

The phytopathogenic fungal isolate St-bt was isolated from $P$. vulgaris, and planted under a greenhouse in Tighanif Mascara (35॰24' N 0॰19'E). Small slices of leaves of an infected plant showing characteristic symptoms were cut sterilely. The slices were then placed on Petri dishes containing a PDA (Potato Dextrose Agar) medium followed by incubation at $25^{\circ} \mathrm{C} / 5-7$ days (Grewal and Jhooty 1984). The purification of the fungal isolate was performed by successive culturing 2-3 times of mycelium on a new PDA medium. The St-bt isolate was identified by observation of the macroscopic and microscopic aspects (Terbeche 2011). Colonies of the isolate St-bt obtained on PDA medium after incubation at $25 \mathrm{C}^{\circ} / 7$ days were examined for their macroscopic aspects like perception, colonies border, and color (Lecellier 2013).

The microscopic observation was carried out for the appearance of the mycelium and the prospective presence of specific forms of reproduction using the technique reported by $\mathrm{Su}$ et al (2012). The method consisted of observation of a part of the mycelium taken from a PDA agar culture at $25^{\circ} \mathrm{C} / 7$ days under an optical microscope (10x and 40x). The activation of sporulation of the St-bt isolate was stimulated by the application of UV light for 16 $\mathrm{h}$ at room temperature followed by incubation in the darkness at $25{ }^{\circ} \mathrm{C}$ from 3 to 5 days. The identification of the isolate St-bt was then performed using the keys proposed by Pitt and Hocking (2009); Hernandez-Perez and du Toit (2000) for the identification of species belonging to the genus Stemphylium. 


\section{Pathogenicity test}

The pathogenicity test was reproduced on Phaseolus vulgris $\mathrm{L}$ plants by the modified method reported by Ben Hassena (2009). $50 \mathrm{~mL}$ of distilled water was added to an old fungal culture of 10 to 15 days on PDA medium. Then, the surface was thoroughly scraped and mixed to release the sporulated forms. The suspension containing (spores + mycelium) was used for contamination by pouring into a pot containing a $P$. vulgaris plant for 2-3 weeks. The onset of symptoms was taken within one week after contamination.

\section{Antifungal activity}

Antagonist activity of the Pseudomonas strains against the isolate St-bt was carried out by the method of dual culture described by Landa et al (1997). Evaluation of the antifungal activity was estimated by calculation of the percent inhibition of the mycelium growth according to the following formula:

$$
\mathrm{PI}=\frac{(\mathrm{r} \text { control }-\mathrm{r} \text { test })}{\mathrm{r} \text { control }} \times 100
$$

Where: PI: percent inhibition;

$r$ test: maximum radial distance of fungus on a line towards the antagonist bacteria in dual culture;

$r$ control: maximum radial distance of fungus inoculated in the center of petri plate).

\section{Statistical analysis}

Results of antifungal activity were represented as the percent inhibition means \pm SD (standard deviation). Those percentages were then analyzed using one-way variance analysis with a significance level of $\mathrm{p}<0.05$. Similarly, when significant differences were found, multiple comparisons were performed using Dennett's test.

\section{RESULTS AND DISCUSSION}

Microorganisms growing in the rhizosphere, particularly Pseudomonas spp., are ideal for use as biocontrol agents of many bacterial and fungal plant diseases. They are known for their high diversity, colonization capacity, plant growth traits involved in stimulation or inhibition plant growth and suppression of different plant pathogens.

\section{Phylogenic identification of Pseudomonas strains}

Phylogenic identification of the two Pseudomonas strains, P4 and P5, was completed by $16 \mathrm{~S}$ DNAr identification. Agarose gel electrophoresis revealed two clear bands of $1500 \mathrm{bp}$ (Figure 1). This showed that the conserved regions of the $16 \mathrm{~S}$ rRNA gene were amplified by the SF and SR primer pair. The phylogenetic analysis related to the two Pseudomonas strains (100\%) to Pseudomonas stutzeri NR 116489 and NR 113652.1 was presented (Figure 2).

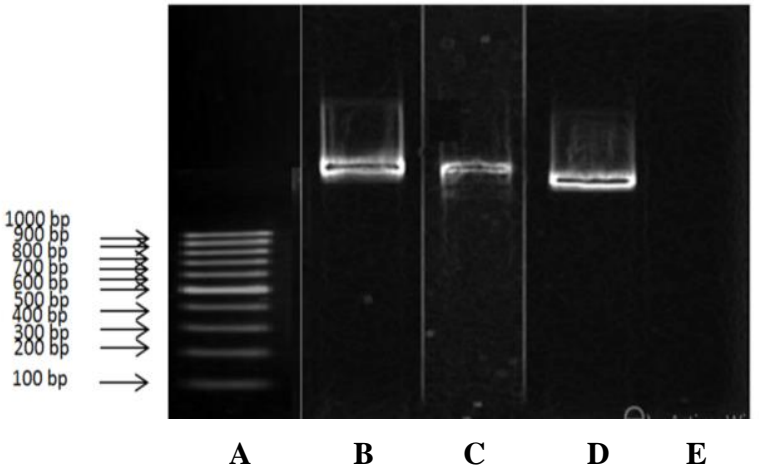

Figure 1. 16SDNAr gene PCR amplicons on 1.5\% agarose gel. DNA bands of about $1500 \mathrm{bp}$ were obtained from the two Pseudomonas strains after 16S RNAr gene PCR. A. SM: size marker; B. Strains P4; C. Strain P5; D. Positive control established by 16S DNAr of strain P25 Pseudomonas grimontii isolated from Vicia sativa (Mokrani et al. 2019); E. Negative control

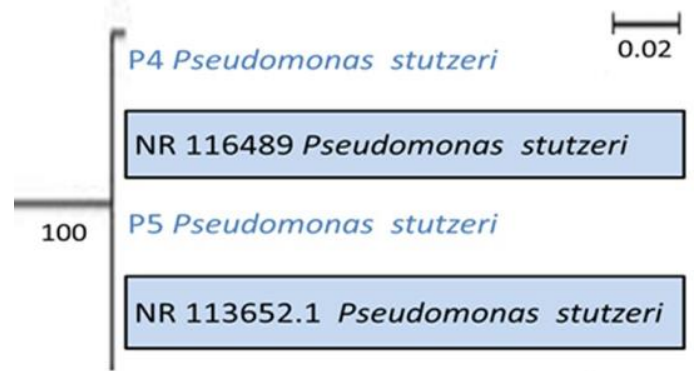

Figure 2 Neighbor-Joining tree obtained using MEGA7, revealing the phylogenetic relationship of the Pseudomonas strains. Bar indicates $2 \%$ sequence divergence

The molecular identification via 16S DNAr of the two Pseudomonas strains attributed them to Pseudomonas stutzeri species. The genus Pseudomonas, is one of the most varied and ecologically widespread groups of microorganisms on the planet (Spiers et al. 2000). Phylogenetic affiliation of different Pseudomonas sp based on 16S rRNA gene suggests that molecular divergence contributes to the genetic range of Pseudomonas sp. The strain determination performed on $16 \mathrm{~S}$ rRNA gene was once related to the nucleotide diversity of Pseudomonas sp in soil rhizosphere community amongst distinct agricultural vegetation (Adhikari et al. 2015). P. stutzeri is a nonfluorescent bacterium widely distributed in the environment. Over the last few years, many improvements have been made in elucidating the taxonomy of this variety of taxonomical groups, demonstrating the clonality of its populations. The species has obtained a lot of interest due to the fact of its unique metabolic properties (Lalucat et al. 2006). Furthermore, strains of $P$. stutzeri have structured in at least seven DNA-DNA similarity groups known as genomovars (Ursing et al. 1995). Confirmation of this system of internal subdivisions was once said following different methods to bacterial phylogeny, which included 16S rRNA gene sequencing (Bennasar et al. 1996). Two individuals of the same genomovar share increased than $70 \%$ DNA-DNA similarity, the common species threshold, 
and these values are reduced and typically much less than $50 \%$ when individuals of distinct genomovars are compared (Rosselló et al. 1991).

\section{Production of $\mathrm{HCN}$}

Pseudomonas strains are known to synthesize a large variety of antibiotics that act effectively in controlling plant pathogens. From those, cyanide hydrogen is the most volatile antibiotic largely described as Pseudomonas biocontrol agents. Evaluation of the capacity of the two $P$. stutzeri stains to produce hydrogen cyanide, revealed a qualitative change of Whatman paper $\mathrm{N}^{\circ} 1$. Color changes from yellow to reddish or reddish-brown confirmed $\mathrm{HCN}$ production (Figure 3).

Soil microorganisms make contributions to soil fertility, soil structure, biodiversity and have a few PGP traits (Barea et al. 1996). One secondary metabolite produced commonly through rhizosphere Pseudomonads is Hydrogen Cyanide (HCN), a gas identified to negatively have an impact on root metabolism and root extension (Alström and Burns 1989; Schippers et al. 1990). This suggests that cyanogenesis, by way of rhizobacteria in the rhizosphere, can adversely influence plant growth (Kremer and Souissi 2001). The degree of HCN produced by means of the use of the rhizobacteria in vitro does not correlate with the determined biocontrol effects, as a result disproving the biocontrol hypothesis. But alternatively, is implicated in geochemical procedures in the substrate, indirectly developing the availability of phosphate (Rijavec and Lapanje 2016). Also, the function of HCN manufacturing by using Pseudomonas fluorescens strain $\mathrm{CHA} 0$ as an antagonistic aspect that contributes to biocontrol of Meloidogyne javanica, the root-knot nematode, in situ (Siddiqui et al. 2006).

\section{Siderophores synthesis}

It has been suggested that the siderophore-mediated competition for iron with soil-borne pathogens is an important mechanism for biological control. Qualitative production of siderophores on CAS agar media by the two $P$. stutzeri strains, showed appearance of characteristic orange halos surrounding growth. This indicated $\mathrm{Fe}$ chelation and revealed siderophores production (Figure 4).

To facilitate iron (III) acquisition, plants and microorganisms, such as fungi and bacteria, produce and excrete strong iron (III) chelators called siderophores (Neilands 1984). Important groups of siderophores consist of hydroxamate siderophores, catecholate (phenolates) siderophores and carboxylate siderophores (Pattan et al. 2017). Various species amongst non-fluorescent Pseudomonas group are capable to produce siderophores (Meyer et al. 2002; Bultreys et al. 2001). The P. stutzeri strain CCUG 36651, was once shown to produce ferrioxamine E (nocardamine) as the major siderophore. This collectively with ferrioxamine $G$ and two cyclic ferrioxamines having molecular masses 14 and 28 atomic mass units decrease than that of ferrioxamine E, suggested to be ferrioxamine D2 and ferrioxamine X1, respectively (Essén et al. 2007). Furthermore, siderophores act as a possible biocontrol agent in opposition to negative phytopathogens and hold the potential to alternative hazardous pesticides (Saha et al. 2016).

\section{IAA production}

Indole acetic acid is one of the most physiologically active and important auxins regulating a range of plant cellular and physiological processes. Qualitative determination of the indole acetic acid revealed that the two strains produced IAA on Luria-Bertani agar supplemented with $5 \mathrm{~mm}$ L-tryptophan. The color obtained was pink-red for the two strains, signifying a moderate IAA production (Figure 5).

Production of IAA was confirmed by paper chromatography compared with the authentic control (10 $\mathrm{mg} / \mathrm{mL}$ ). After revelation with Salkowski's reagent, chromatogram of IAA extracts showed two pinkish spots $\left(\mathrm{R}_{\mathrm{f}}=0.53\right)$ corresponding to the authentic IAA (Figure 6).

Indole acetic acid production is another essential PGPR trait implicated directly in stimulation of plant increase. IAA is a major property of rhizosphere bacteria that plays a main function in plant growth and development; specifically in modifying cell division, cell differentiation, cell expansion, and lateral root formation (Pant and Agrawal 2014). Equally, IAA incites in the production of longer roots with multiplied wide variety of root hairs and root laterals which are involved in nutrient uptake (Datta et al. 2000).

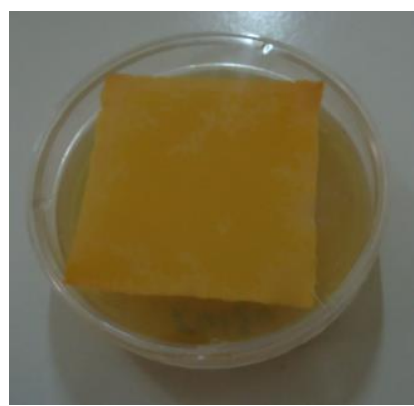

A

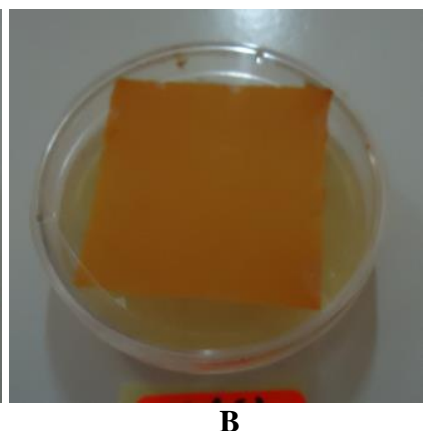

B
Figure 3. Qualitative production of hydrogen cyanide by $P$. stutzeri strains on agar medium (a: weak reddish color for strain P4 indicating low production; b: reddish-brown color for strain P5 meaning moderate production)

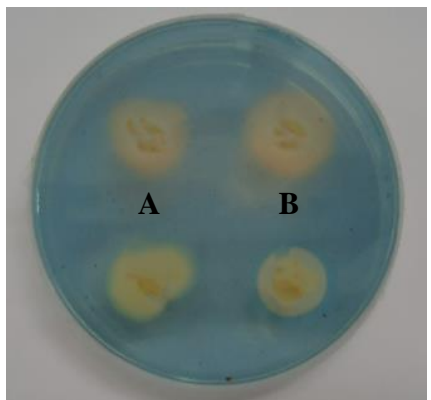

Figure 4. Qualitative productions of siderophores by Pseudomonas stutzeri strains on CAS-medium (a: small orange halo surround growth for strain P4 meaning low production; b: large orange halo surround colonies for strain P5 revealing moderate production) 


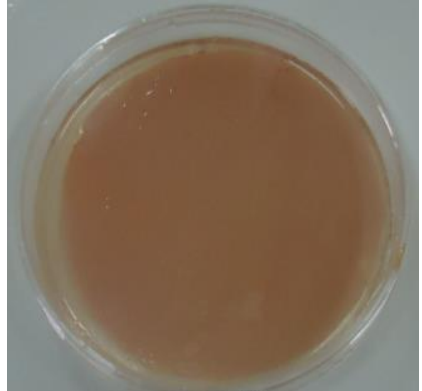

Figure 5. Production of indole acetic acid by strain P5 Pseudomonas stutzeri (red color reflecting moderate IAA production)

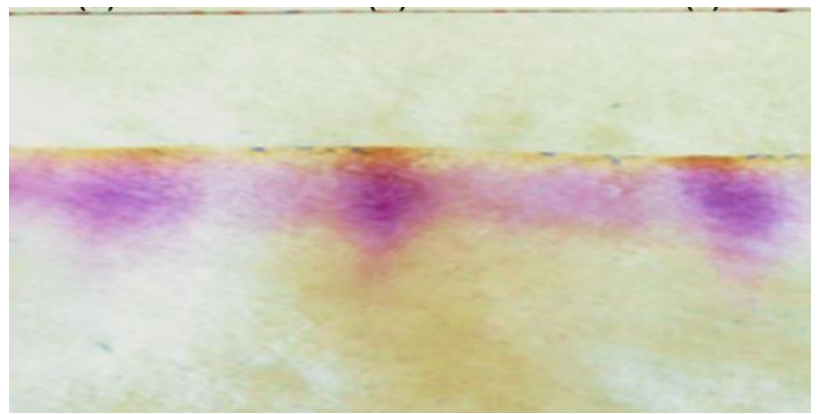

$\mathbf{A}$ B

C

Figure 6. IAA chromatogram. A. Control; B. IAA extract of strain P4; C. IAA extract of strain P5

Also, it stimulates cell elongation via enhancing positive conditions like: extend in osmotic contents of the cell, rising in permeability of water into cell, limiting in wall pressure, amplifying in cell wall synthesis, inducing RXA, and protein synthesis. Furthermore, IAA enhances embial activity, inhibits or prolongs abscission of leaves, induces flowering and fruiting (Zhao 2010).

\section{Isolation and identification of fungus \\ Isolation of fungus}

The fungus isolates St-bt was isolated from $P$. vulgaris showing leaf blight disease symptoms. Characteristic small yellow-brown tasks were observed on the leaves area (Figure 7).

In this study, isolation of fungal diseases occurring in $P$. vulgaris cultures revealed fungus St-bt showing characteristic symptoms of leaf blight disease. Riley et al (2002) had reported that control measures of plan pathogens depend on proper identification of diseases and the causal agents. Therefore, diagnosis is one of the most important aspects of a plant pathologist's training. It includes identification of affected plants, recognizing healthy plant appearance, identifying attribute symptoms, and checking distribution of symptoms.

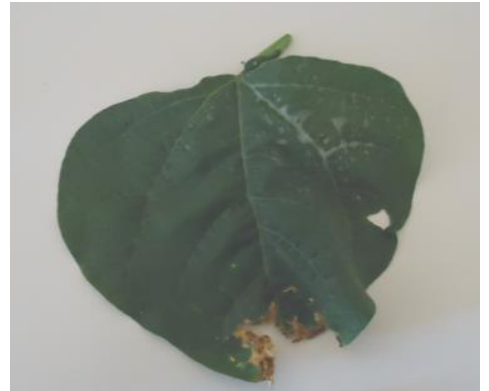

Figure 7. Leaf blight caused by fungus isolate St-bt on Phaseolus vulgaris leaves

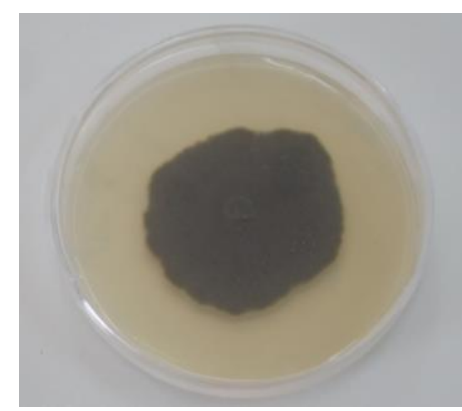

Figure 8. Macroscopic aspect of isolate St-bt on PDA medium

\section{Macroscopic and microscopic identification}

After isolation on PDA medium, fungus isolate St-bt revealed characteristic black colonies surrounded with white color in the edge (Figure 8). Furthermore, colonies were velvety with irregular shape, black in the revers, marked by less speed growth forming colony of $26 \mathrm{~mm}$ at the end of 7 days of incubation.

Microscopic examination of isolate St-bt showed mycelium characterized by ramified septa, typical mature and immature conidia. Evenly, conidia were always isolated and never in chains, an essential distinguishing feature between genera Alternaria and Stemhyllium (Figure 9). Immature conidia were ovate to cylindrical, brown with one to two transverse septa. Mature conidia were dark brown cylindrical, with a pointed apex; they assume cottony longitudinal and transverse septations with an irregular outline.

In this present study, macroscopic and microscopic identification of the isolate St-bt had attributed it to Stemphylium botryosum. Hosen et al (2009) mentioned that the colonies of $S$. botryosum on PDA medium are velvety to cottony in texture with a grey, brown, or brownish-black color colony. Also, conidia are colored and septated were determined amongst $S$. botryosum strains (Caudillo-Ruiz et al. 2017). Furthermore, Boutkhil (2012) had reported that $S$. botryosum is a frequent fungus isolated from bean cultures. The fungus Stemphylium botryosum has been suggested to be very widespread in temperate and subtropical regions, where it is established in a wide range of economically essential vegetation (Mwakutuya 2006). 


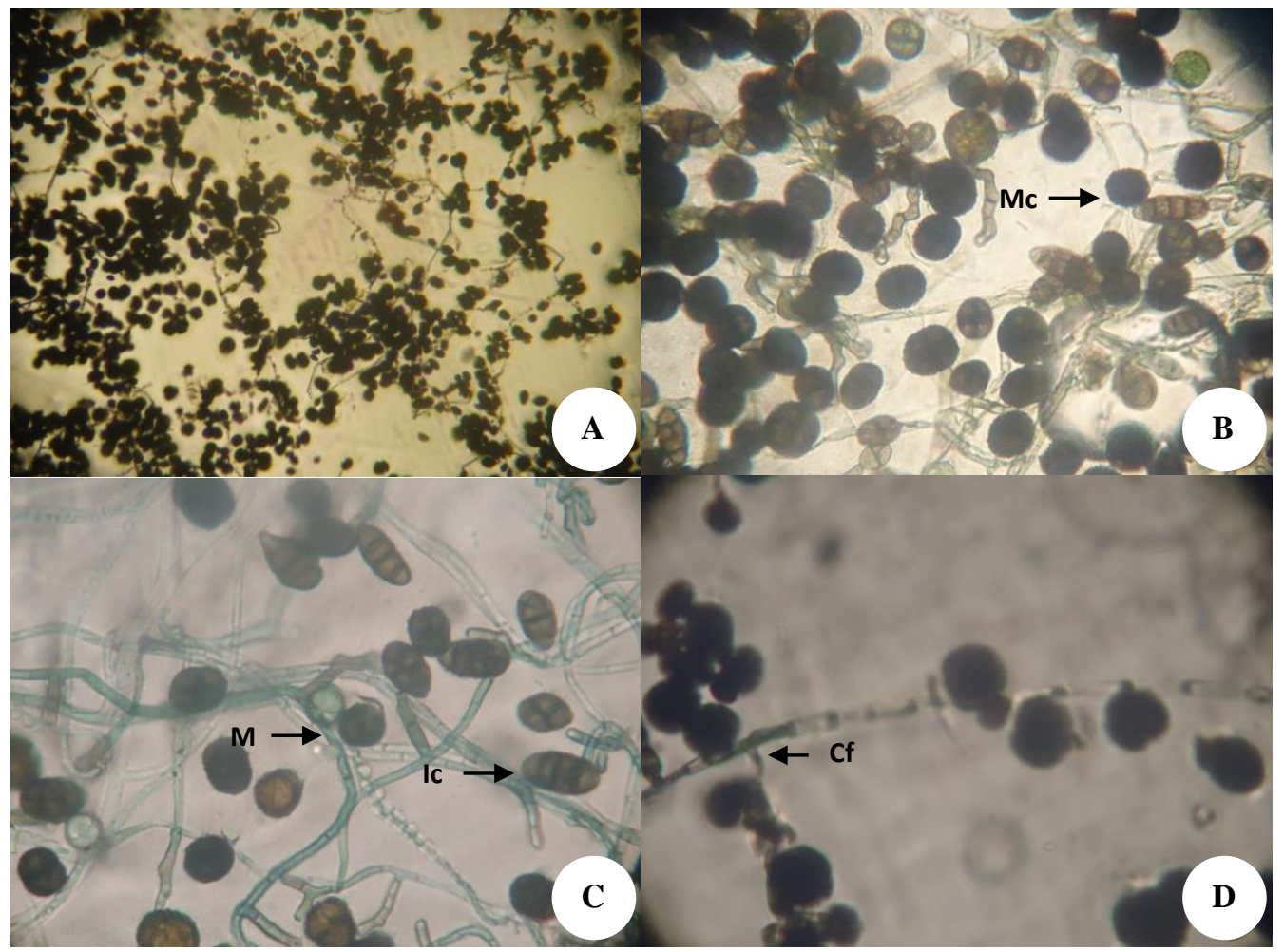

Figure 9. Microscopic observation of isolate St-bt (A and B: showed abundant spores after activation of fungus culture by UV light for $16 \mathrm{~h}$ at room temperature $(10 \mathrm{x})$ and $(40 \mathrm{x})$, respectively; C: plentiful mycelium without culture activation $(40 \mathrm{x})$; $\mathrm{D}$ : indicated conidiophore (Cf) (40x); Ic: immature conidia; Mc: mature conidia; M: Mycelium

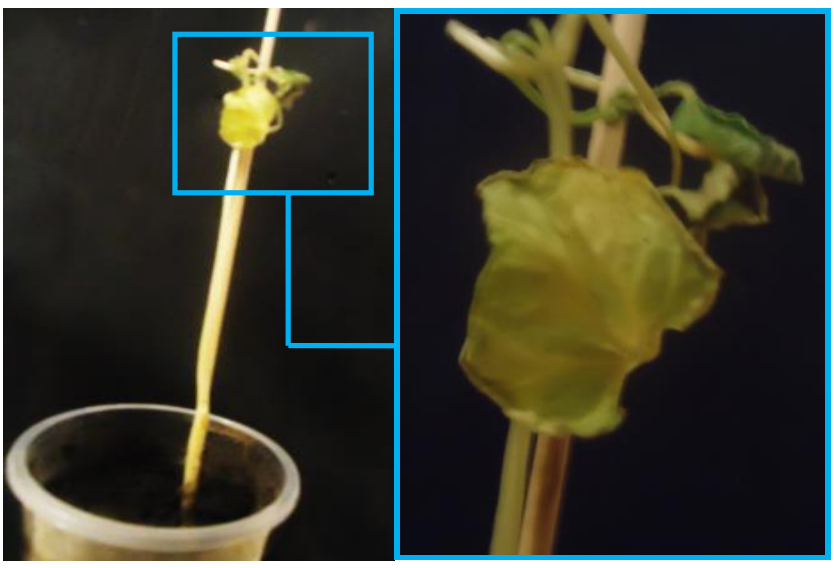

Figure 10. Pathogenicity test of isolate St-bt Stemphylim botryosum on Phaseolus vulgaris (A and B: characteristic symptom indicating yellow-brown tasks of the infected leaves)

\section{Pathogenicity test}

The purpose of the pathogenicity test was to reproduce disease symptoms observed on $P$. vulgaris leaves a moment of isolation to confirm the pathogenicity of the isolate St-bt. This test revealed symptomatic stemphyliose leaf blight disease. It was characterized by yellow-brown tasks observed throughout the leaves area (Figure 10).

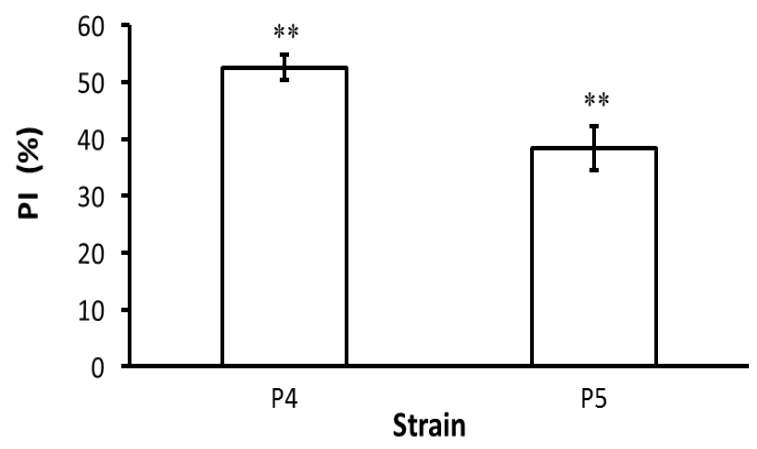

Figure 11. Antifungal activities of Pseudomonas stutzeri strains against isolate St-bt (PI: percent inhibition; **: very significant difference at $\mathrm{p}<0.05)$.

In conclusion, current findings led to conclude that $P$. stutzeri strains are potent antifungal agents against isolate St-bt in vitro trials. Thus, by producing effective PGP traits like $\mathrm{HCN}$ and siderophores involved in the pathogen suppression. However, further evaluation of the effectiveness of strains P4 and P5 for biological control of bean leaf blight caused by isolated St-bt on-field culture and the design formulations and applications should be done in the field. 


\section{REFERENCES}

Adhikari A, Nandi S, Bhattacharya I, De Roy M, Mandal T, Dutta S. 2015. Phylogenetic analysis based evolutionary study of $16 \mathrm{~S}$ rRNA in known Pseudomonas sp. Bioinformation 11: 474-480. DOI: 10.6026/97320630011474.

Agrios GN. 1988. Plant Pathology, 3rd. ed. Academic Press, San Diego, USA.

Alström S, Burns RG. 1989. Cyanide production by rhizobacteria as a possible mechanism of plant growth inhibition. Biol Fert Soils 7: 232238. DOI: $10.1007 / \mathrm{bf00709654.}$

Altieri M. 1989. Agroecology: a new research and development paradigm for world agriculture. Agric Ecosyst Environ 27: 37-46.

Barea JM, Calvet C, Estaun V, Camprubi A. 1996. Biological control as a key component in sustainable agriculture. Plant and soil 185: 171172. DOI: $10.1007 / \mathrm{bf0} 2257521$.

Ben Hassena A. 2009. Induction de la réaction de défense chez les plantes pour lutter contre les maladies. [Mémoire d'ingénieur]. Institut national agronomique, Tunis. [France]

Bennasar A, Rosselló-Mora R, Lalucat J, Moore ERB. 1996. 16S rRNA gene sequence analyses relative to genomovars of Pseudomonas stutzeri and proposal of Pseudomonas balearica sp. nov. Intl J Syst Bacteriol 46: 200-205. DOI: 10.1099/00207713-46-1-200.

Boutkhil S. 2012. Les principaux maladies fongiques de 1'olivier (Olea europea L) en Algérie: réparation géographique et importance. [Mémoire de magister]. Université Oran 1 Ahmed Ben Bella, Oran [Algérie].

Bric JM, Bostock RM, Silverstone SE. 1991. Rapid in situ assay for indole acetic acid production by bacteria immobilized on nitrocellulose membrane. Applied and Environmental Microbiology 57: 535-538.

Bultreys A, Gheysen I, Maraite H, de Hoffmann E. 2001. Characterization of Fluorescent and Nonfluorescent Peptide Siderophores Produced by Pseudomonas syringae Strains and Their Potential Use in Strain Identification. Appl. Environ. Microbiol 67: 1718-1727. DOI: 10.1128/aem.67.4.1718-1727.2001.

Caudillo-Ruiz KB, Bhadauria V, Banniza S. 2017. Aetiology of Stemphylium blight on lentil in Canada. Canadian J Plant Pathol 39 422-432. DOI: 10.1080/07060661.2017.1378728.

Chauhan A, Ranjan A, Jindal T. 2018. Biological control agents for sustainable agriculture, safe water and soil health. In: Jindal T (ed.) Paradigms in Pollution Prevention. Springer, Cham.

Compant S, Duffy B, Nowak J, Clément C, Barka EA. 2005. Use of plant growth-promoting bacteria for biocontrol of plant diseases: principles, mechanisms of action, and future prospects. Appl Environ Microbiol 71: 4951-4959. DOI: 10.1128/aem.71.9.4951-4959.2005.

Cook RJ. 1993. Making greater use of introduced microorganisms for biological control of plant pathogens. Annu Rev Phytopathol 31: 5380. DOI: 10.1146/annurev.phyto.31.1.53.

Datta C, Basu P. 2000. Indole acetic acid production by a Rhizobium species from root nodules of a leguminous shrub Cajanus cojan. Microbiol Res 155: 123-127. DOI: 10.1016/s0944-5013(00)80047-6.

Essén SA, Johnsson A, Bylund D, Pedersen K, Lundström US. 2007. Siderophore production by Pseudomonas stutzeri under aerobic and anaerobic conditions. Appl Environ Microbiol 73: 5857-5864. DOI:org/10.1128/aem.00072-07.

Gimenez E, Salinas M, Manzano-Agugliaro F. 2018. Worldwide research on plant defense against biotic stresses as improvement or sustainable agriculture. Sustainability 10: 391. DOI: 10.3390/su10020391.

Goldman GH, Hayes C, Harman GE. 1994. Molecular and cellular biology of biocontrol by Trichoderma spp. Trends Biotechnol 12: 478-482. DOI: 10.1016/0167-7799(94)90055-8.

González de Molina M, Soto Fernández D, Infante-Amate J, Aguilera E, VilaTraver J, Guzmán GI. 2017. Decoupling food from land: the evolution of Spanish agriculture from 1960 to 2010. Sustainability 9: 2348. DOI: $10.3390 / \mathrm{su} 9122348$.

Goswami D, Thakker JN, Dhandhukia PC. 2016. Portraying mechanics of plant growth-promoting rhizobacteria (PGPR): a review. Cogent Food Agric 2: 1-19. DOI: 10.1080/23311932.2015.1127500.

Grewal RK, Jhooty JS. 1984. Rating of gram blight in fungicidal trials. Crop Improv 11: 71-72.

Hernandez-Perez P, du Toit LJ. 2006. Seed borne Cladosporium variable and Stemphylium botryosum in spinach. Plant Dis 90: 137-145.

Hosen MI, Ahmed AU, Zaman J, Ghosh S, Hossain KMK. 2009. Cultural and physiological variation between isolates of Stemphylium botryosum the causal of Stemphylium blight disease of lentil (Lens culinaris).World J Agric Sci 5: 94-98.

Kremer RJ, Souissi T. 2001. Cyanide production by rhizobacteria and potential for suppression of weed seedling growth. Curr Microbiol 43: 182-186. DOI: $10.1007 / \mathrm{s} 002840010284$

Kuang-Ren C, Turksen S, Umran E, Timmer LW, Peter PU. 2003. Indole derivatives produced by the fungus Colletotrichum acutatumc causing lime anthracnose and post bloom fruit drop of citrus. FEMS Microbiol Lett 226: 23-30. DOI: 10.1016/s0378-1097(03)00605-0.

Lalucat J, Bennasar A, Bosch R, García-Valdés E, Palleroni NJ. 2006. Biology of Pseudomonas stutzeri. Microbiol Mol Biol Rev 70: 510547. DOI: $10.1128 / \mathrm{mmbr} .00047-05$.

Landa BB, Hervas A, Bettiol W, Jimenez-Diaz RM. 1997. Antagonistic activity of Bacteria from the Chickpea Rhizosphere against Fusarium Oxysporium f. sp. ciceris. Phytoparasitica 25: 305-318. DOI: $10.1007 / \mathrm{bf02981094.}$

Lecellier A. 2013. Caractérisation et identification des champignons filamenteux par spectroscopie vibrationnelle. [Thèse de doctorat]. Université de Reims Champgne-Ardenne, Reims. [France].

Lorck H. 1948. Production of hydrocyanic acid by bacteria. Physiologia Plantarum 1: 142-146. DOI: 10.1111/j.1399-3054.1948.tb07118.x.

Meyer JM, Geoffroy VA, Baida N, Gardan L, Izard D, Lemanceau P, Achouak W, Palleroni NJ. 2002. Siderophore typing, a powerful tool for the identification of fluorescent and non-fluorescent Pseudomonads. Appl Environ Microbiol 68: 2745-2753. DOI: 10.1128/aem.68.6.2745-2753.2002.

Mishra J, Arora NK. 2017. Secondary metabolites of fluorescent pseudomonads in biocontrol of phytopathogens for sustainable agriculture. Appl Soil Ecol 125: 35-45. DOI: 10.1016/j.apsoil.2017.12.004.

Mittler R, Blumwald E. 2010. Genetic engineering for modern agriculture: challenges and perspectives. Ann Rev Plant Biol 61: 443-462. DOI: 10.1146/annurev-arplant-042809-112116.

Mokrani S, Belabid L, Bejaoui B, Nabti E. 2018a. Growth stimulation of Phaseolus vulgaris L plantules by strain Bacillus amyloliquefaciens Hla producer of beneficial agricultural enzymes. JOJ Hortic Arboric 2: $1-7$.

Mokrani S, Rai A, Belabid L, Cherif A, Cherif H, Mahjoubi M, Nabti E. 2019. Pseudomonas diversity in western Algeria: role in the stimulation of bean germination and common bean blight biocontrol. European J Plant Pathol 153: 397-415. DOI: 10.1007/s10658-0181566-9.

Morrissey JP, Abbas A, Mark L, Cullinane M, O’Gara F. 2004a. Biosynthesis of antifungal metabolites by biocontrol strains of Pseudomonas. In: Ramos JL (ed.) The Pseudomonads, Vol. III. Kluwer Press, Dordrecht.

Mwakutuya. 2005. Epidemiology of Stemhylium blight on lentil (Lens culinaris) in Saskatchewan. [Dissertation]. University of Saskatchewan, Saskatoon, SK, Canada]

Neilands JB. 1984. Siderophores of bacteria and fungi. Microbiol Sci 1: 914.

Newton AC, Johnson SN, Gregory PJ. 2011. Implications of climate change for diseases, crop yields and food security. Euphytica 179: 318. DOI: $10.1007 / \mathrm{s} 10681-011-0359-4$

Nobutaka S. 2008. Biological control of fungal plant diseases using antagonistic bacteria. J Gen Plant Pathol 74: 459-460. DOI: 10.1007/s10327-008-0131-3.

Nogórska K, Bikowski M, Obuchowski M. 2007. Multicellular behavior and production of a wide variety of toxic substances support usage of Bacillus subtilis as a powerful biocontrol agent. Acta Biochim Pol 54: 495-508.

O’Sullivan DJ, O'Gara F. 1992. Traits of fluorescent Pseudomonas spp. involved in suppression of plant root pathogens. Microbiol Rev 56: 662-276.

Pant G, Agrawal PK. 2014. Isolation and characterization of indole acetic acid-producing plant growth-promoting rhizobacteria from rhizospheric soil of Withania somnifera. J Biol Sci Opin 2: 377-383. DOI: 10.7897/2321-6328.02687.

Pattan, J, Kajale S, Pattan S. 2017. Isolation, production and optimization of siderophores (iron chelators) from Pseudomonas fluorescence NCIM 5096 and Pseudomonas from soil rhizosphere and marine water. Intl J Curr Microbiol App Sci 6: 919-928. DOI: 10.20546/ijcmas.2017.603.109

Pitt JI, Hocking AD. 2009. Fungi and food spoilage. 2nd ed. Blackie Academic and Professional. Glasgow, Lanarkshire, UK. 
Rijavec T, Lapanje A. 2016. Hydrogen cyanide in the rhizosphere: not suppressing plant pathogens, but rather regulating availability of phosphate. Front Microbiol 7: $1785 . \quad$ DOI: 10.3389/fmicb.2016.01785.

Riley MB, Williamson MR, Maloy O. 2002. Plant disease diagnosis. The plant health instructor.www.apsnet.org/edcenter/intropp/topics/pages/plantdisease diagnosis.aspx.

Rosselló R, García-Valdés E, Lalucat J, Ursing J. 1991. Genotypic and phenotypic diversity of Pseudomonas stutzeri. Syst Appl Microbiol 14: 150-157. DOI: 10.1016/s0723-2020(11)80294-8.

Saha M, Sarkar S, Sarkar B, Sharma BK, Bhattacharjee S, Tribedi P. 2016. Microbial siderophores and their potential applications: a review. Environ Sci Poll Res 23: 3984-3999. DOI: 10.1007/s11356015-4294-0.

Saleh M, El-Wakeil N, Elbehery H, Gaafar N, Fahim S. 2017. Biological Pest Control for Sustainable Agriculture in Egypt. In: Barceló D, Kostianoy AG (eds.). The Handbook of Environmental Chemistry. Springer Press, Berlin.

Schippers B, Bakker A, Bakker P, van Peer R. 1990. Beneficial and deleterious effects of $\mathrm{HCN}$-producing pseudomonads on rhizosphere interactions. Plant Soil 129: 75-83. DOI: 10.1007/bf00011693.

Siddiqui IA, Shaukat SS, Sheikh IH, Khan A. 2006. Role of cyanide production by Pseudomonas fluorescens CHA0 in the suppression of root-knot nematode, Meloidogyne javanica in tomato. World $\mathrm{J}$ Microbiol Biotechnol 22: 641-650. DOI: 10.1007/s11274-005-9084 2.

Spiers AJ, Buckling A, Rainey PB. 2000. The causes of Pseudomonas diversity. Microbiology 146: 2345-2350. DOI: 10.1099/00221287146-10-2345.

Stockwell VO, Stack JP. 2007. Using Pseudomonas spp. for integrated biological control. Phytopathology 97: 244-249.

Su YY, Qi YL, Cai L. 2012. Induction of sporulation in plant pathogenic fungi. Mycology 3: 195-200.

Tagele SB, Kim SW, Lee HG, Kim HS, Lee YS. 2018. Effectiveness of multi-trait Burkholderia contaminans KNU17BI1 in growth promotion and management of banded leaf and sheath blight in maize seedling. Microbiol Res 214: 8-18. DOI: 10.1016/j.micres.2018.05.004.
Terbeche F. 2011. Etude de l'activité protéolytique et le profil protéique total chez Ascochyta rabiei. [Mémoire de magister].Université Oran 1 Ahmed Ben Bella, Oran, Algérie. [France]

Thilagam R, Kalaivani G, Hemalatha N. 2018. Isolation and identification of phytopathogenic fungi from infected plant parts. Intl J Curr Pharmaceut Res 10: 1-26. DOI: 10.22159/ijcpr.2018v10i1.24404.

Thomashow LS, Weller DM. 1996. Current concepts in the use of introduced bacteria for biological disease control: mechanisms and antifungal metabolites. In: Stacey G, Keen NT (eds.). Plant-Microbe Interact. Chapman and Hall, New York.

Trivedi P, Pandey A, Palni LMS. 2008. In vitro evaluation of antagonistic properties of Pseudomonas corrugata. Microbiol Res 163: 329-336. DOI: 10.1016/j.micres.2006.06.007.

Ursing JB, Rossellö-Mora RA, Garcia-Valdes E, Lalucat J. 1995.Taxonomic note: a pragmatic approach to the nomenclature of phenotypically similar genomic groups. Intl J Syst Evol Microbiol 45: 604-604. DOI: 10.1099/00207713-45-3-604.

Vinale F, Sivasithamparam K, Ghisalberti EL, Marra R, Woo SL, Lorito M. 2008. Trichoderma plant-pathogen interactions. Soil Biol Biochem 40: 1-10.

Wallace RL, Hirkala DL, Nelson LM. 2017. Mechanisms of action of three isolates of Pseudomonas fluorescens active against postharvest grey mold decay of apple during commercial storage. Biol Contr 117: 13-20. DOI: 10.1016/j.biocontrol.2017.08.019.

Wei G, Kloepper JW, Tuzun S. 1996. Induced systemic resistance to cucumber diseases and increased plant growth by plant growthpromoting rhizobacteria under field conditions. Phytopathology 86 : 221. DOI: $10.1094 /$ phyto-86-221.

Weller DM. 2007. Pseudomonas biocontrol agents of soil-borne pathogens: looking back over 30 years. Phytopathology 97: 250-256. DOI: 10.1094/phyto-97-2-0250.

William S, Feil H, Copeland A. 2012. Bacterial genomic DNA isolation using CTAB. Sigma 50: 6876.

Yeole RD, Dave BP, Dube HC. 2001. Siderophores production by fluorescent pseudomonads colonizing roots of certain crop plants. Indian J Experimental Biology 39: 464-468.

Zhao Y. 2010. Auxin biosynthesis and its role in plant development. Annu. Rev. Plant Biol. 61: 49-64. DOI: 10.1146/annurev-arplant042809-112308. 